Österreichische Akademie der Wissenschaften / Austrian Academy of Sciences AAS WORKING PAPERS IN SOCIAL ANTHROPOLOGY Volume 27

\author{
Jos D. M. Platenkamp

\section{STRANGERS, THE STATE \\ AND THE SELF IN GERMANY: A COMPARATIVE VIEW}
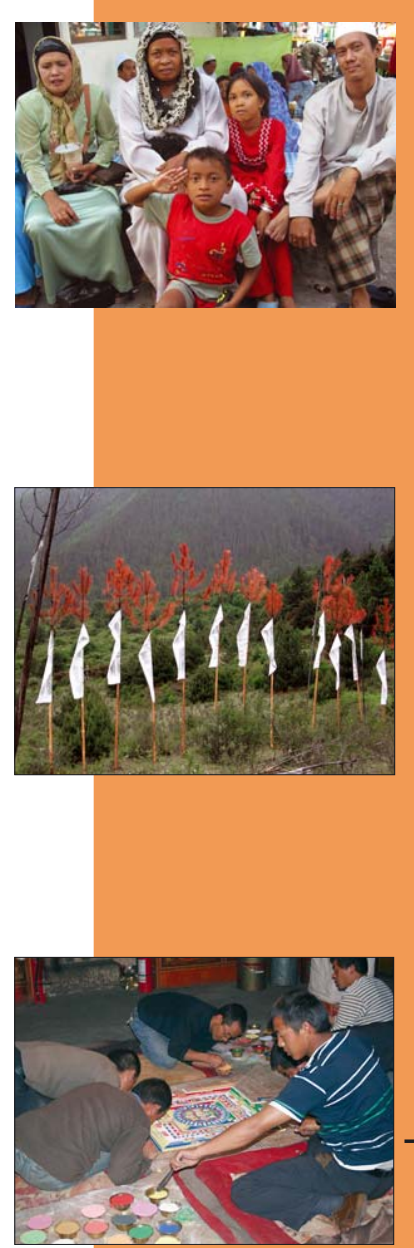


\section{AAS Working Papers in Social Anthropology / \\ ÖAW Arbeitspapiere zur Sozialanthropologie}

ISBN-Online: 978-3-7001-7548-3

DOI:10.1553/wpsa27

Wien 2014

\section{Editors / Herausgeber:}

Andre Gingrich \& Guntram Hazod

(C) Institut für Sozialanthropologie

Zentrum Asienwissenschaften und Sozialanthropologie

Österreichische Akademie der Wissenschaften

Apostelgasse 23

A-1030 Wien

Fax: 01/ 51581-6450

E-Mail: sozialanthropologie@oeaw.ac.at 


\title{
STRANGERS, THE STATE AND THE SELF IN GERMANY: A COMPARATIVE VIEW*
}

\author{
Jos D. M. PlatenKamp
}

\section{Introduction}

When, in 2010, the German chancellor Angela Merkel dismissed the "multicultural approach" as an "absolute failure", and the Bavarian minister-president Horst Seehofer insisted that the "integration" of immigrants could only be achieved if they complied with "our German Leitkultur" they both reiterated the essentialist reifications of a 'national identity' characterising the public and political discourses of many European nation-states. There indeed appears to be a growing consensus that the representatives of 'other cultures' living in Europe not only should conform to the laws of the State but also subscribe - at least in the public sphere - to those representations that identify the society in question as a "community of values". The culturally specific actions and values of immigrants might be tolerated in the private domain, provided they do not conflict with the values of the nation-state in question. ${ }^{3}$

A similar consensus seems to prevail at the level of the European Union. The Preamble of the Treaty on European Union of 2008 propagated the idea that its member States share a "common destiny", originating in the "cultural, religious and humanist inheritance of Europe", and therefore constitute a common "community of values"4 as well. These orientations are evidently grounded in European paradigms of world history and philosophy. They draw on ideas deriving inter alia from Enlightenment, Christian morality and political secularism that are assigned a universal relevance. They inform many of the international legal and political discourses and their global advocacy is deemed a solemn task.

And yet, it is part of the same value configurations to advocate the incorporation of 'strange' non-European representations into the personal repertoire of each individual citizen. Originating in Renaissance and Romanticist thought, and transmitted through 'classical' education, the idea pertains that the 'oriental' other may be valued as a source of metaphysical wisdom, moral purity, artistic originality and proximity to Nature.

* The present contribution is based on a paper presented by the author in the framework of the International Guest Lecture Series at the Institute for Social Anthropology of the Austrian Academy of Sciences, Vienna, March 272014.

${ }^{1}$ Süddeutsche Zeitung 16.10.2010.

${ }^{2}$,Integration heißt nicht nebeneinander, sondern miteinander leben auf dem gemeinsamen Fundament der Werteordnung unseres Grundgesetzes und unserer deutschen Leitkultur, die von den christlichjüdischen Wurzeln und von Christentum, Humanismus und Aufklärung geprägt ist“ (Horst Seehofer, ibid.); cf. note 4.

${ }^{3}$ Compare the answer, once given by a Dutch Cabinet Minister to the question why the Netherlands is the only State in Europe to uphold the categorical distinction between 'autochthonous' and 'nonindigenous' (allochthoon) citizens to classify the descendants of immigrants: "How does one get rid of this [distinction between] autochthoon and allochthoon? At one point one is Dutch [...] when one has obtained a place in Dutch society, when one participates in it, subscribes to our values and norms [...] what one does behind one's front door is one's own business" (Anil Ramdas, www.nrc.nl/ramdas/ artikel/1103538384826.html; my translation and italics).

${ }^{4}$ As such are identified the "universal values of the inviolable and inalienable rights of the human person, freedom, democracy, equality and the rule of law" (Preamble of the Treaty on European Union, Official Journal C 115 , 09/05/2008). 
A peculiar configuration thus appears to characterise the valuation of people, ideas and actions of 'strange' provenance. What is excluded at the level of the nation-state should be included at the level of the individual's life experience. As far as this valuation of 'strangers' is concerned a curious gap opens up between the nation-state and the individual Self.

To examine such value configurations let us recall Salman Rushdie's words that "the only one who sees the whole picture [...] is the one who steps out of the frame". ${ }^{5}$ A "view from afar" is needed, and social anthropology is the social science par excellence to provide such a perspective. For only when observed through the lenses of other societies may one perceive the cultural idiosyncrasy of our own ideas and values more sharply. So let me therefore turn to some Southeast Asian societies first, and see how they value the presence of 'strangers' in their midst.

\section{The differential origins of the person in Southeast Asia}

In contrast to the cultural homogeneity proclaimed by the European nation-state and the European Union many Southeast Asian societies of old apply heterogeneous models in conceptualising their identity. These models are built from relations between opposed categories of a cosmological, social, political and ontological nature. These manifest themselves both at the level of the individual person and at the level of society at large. Without going into details let me sketch some of these dimensions.

In many regions of the world mythical narratives have been recorded that address the question under what conditions a person may be considered complete. Known as myths about the 'half-person' or "unilateral figure" they relate how a first human being is born with a remarkable deficiency. In Rodney Needham's words: "The figure is generally a man or, as a mythical creature, has the form of a man; occasionally it can be a woman or some other entity such as a spirit in quasi-human form. What has to be imagined is the lateral half of a symmetrical body parted longitudinally. Normally, in order to move, it hops on its solitary leg". ${ }^{8}$ In Southeast Asia such myths were collected among the Iban of Borneo, ${ }^{9}$ the Loloda of the North Moluccas ${ }^{10}$ and Roti in Southeast Indonesia, ${ }^{11}$ among others. The myths do not assess the person's deficiency in physiological terms but attribute it to the absence of certain primordial socio-cosmological relationships. They describe how these relationships come into being one after another, and only after this process has been accomplished will the protagonist have become complete. Of course, the types of relationships involved vary considerably from one society to another - after all, they constitute a kind of blueprint of the social order in itself. ${ }^{12}$ Nevertheless the myths share a basic theme (a mythème to speak with Lévi-Strauss)

\footnotetext{
${ }^{5}$ S. Rushdie, The ground beneath her feet. New York: Henry Holt \& Company, 1999.

${ }^{6}$ C. Lévi-Strauss, Le regard éloigné. Paris: Plon, 1983.

7 E.g. A. Szabo, "Der halbe Mensch und der biblische Sündenfall”, Paideuma 2: 96-100, 1941; A. E. Jensen, "Die mythische Vorstellung vom halben Menschen", Paideuma 5: 23-43, 1950.

${ }^{8}$ R. Needham, "Unilateral Figures”, in: R. Needham, Reconnaissances. Toronto: Toronto University Press, pp. 17-40, 1980, p. 20.

${ }^{9}$ C. Sather, "The One-Sided One: Iban Rice Myths, Agricultural Ritual and Notions of Ancestry", in: A. R. Walker (ed.), Rice in Southeast Asian Myth and Ritual. Special Issue Contributions to Southeast Asian Ethnography 10: 119-50, 1994.

${ }^{10}$ M. J. van Baarda, "Het Loda'sch in vergelijking met het Galela'sch dialect op Halmaheira, gevolgd door Loda'sche teksten”, Bijdragen tot de Taal-, Land-en Volkenkunde 56: 317-496, 1904.

${ }^{11}$ J. J. Fox, n.d., The Origin of the Dog. Unpublished typescript.

${ }^{12}$ J. D. M. Platenkamp, “Des personnes incomplètes aux sociétés accomplies”, l'Homme 174: 125-60, 2005.
} 
in common. The initial deficiency of the protagonist does not affect the living condition of his body as such - that body does grow and 'hop around'. The incompleteness manifests itself in the person's appearance as perceived by others. I shall return to this point presently.

As said, the social and cosmological relationships that grant the first human beings their completeness are highly diverse, but in these and other myths about the genesis of primeval ancestors certain types recur time and again. Two types of origins and the different social dimensions emanating from them are distinguished. An autochthonous origin is ascribed to the 'living' condition of the human body and of domesticated plants and animals. The first human beings may have born from indigenous plant species such as rice plants, ${ }^{13}$ pumpkins ${ }^{14}$ or root crops $^{15}$ or have emerged directly from the local soil. ${ }^{16}$ Such a 'living' condition of humans is not perceived in physical terms nor is that of the soil understood in ecological terms. The condition results from the incorporation of a 'life-giving' component from sources over which indigenous spirits wield authority. Withdrawn from the land to be embodied in primeval humans, and in the children born ever since, such 'lifegiving' components will eventually return to these indigenous sources at death - a process requiring the performance of primary mortuary rituals. And once the society in question has been fully established, it is mostly a person's maternal relatives and their ancestors who mediate the transfer of 'life' from such indigenous sources at birth and its eventual return there at death. Whatever the specific categories of kin and the ritual tasks imposed upon them, in reference to this 'life-giving' dimension each person is of autochthonous provenance.

The mere embodiment of this 'life-giving' principle, however, does not generate complete human beings. The general idea pertains that, if the incorporation of 'life' is to grant humans their lifetime, this embodiment must be socially authorised. A social condition must be superimposed on the conjunction between body and life - an imperative that assumes different forms throughout the region. In many societies this social condition is conceptualised as an additional component of the person. Signifying a dimension of human existence that differs radically from that of the body's 'living' condition I have labelled such component parts as a person's 'image' or 'Gestalt'. ${ }^{17}$ It may be deemed present in the liver, the blood or the heart, but it is indexed above all by the person's visible appearance as projected, for instance, in the shadow that he casts (hence such conventional renderings of these concepts as 'shadow soul', 'alter ego' etcetera).

The mere fact that a person's 'image' is visible to the outside world points towards an important idea. It is the acknowledgement by others that gives a person's 'image' its true social value. For neither can such a social acknowledgement stem from the person's subjective perception of the self, nor should it depend on these other persons' subjective assessment of that person's 'image'. It

\footnotetext{
${ }^{13}$ E.g. in Java and Bali: M. Appel, Dewi Sri und die Kinder des Putut Jantaka: Beziehungen zwischen Mensch und Reis in Mythologie und Brauchtum auf Java und Bali. München: Anacon-Verlag, 1991.

${ }^{14}$ E.g. Rmeet of North Laos: G. Sprenger, Die Männer, die den Geldbaum fällten: Konzepte von Austausch und Gesellschaft bei den Rmeet von Takheung. Laos, Berlin: LitVerlag, 2006.

${ }^{15}$ E.g. Laboya of Sumba: D. C. Geirnaert-Martin, The woven land of Laboya. Socio-cosmic ideas and values on West Sumba, Eastern Indonesia. Leiden: CNWS, 1992.

${ }^{16}$ E.g. Marobo of East Timor, B. Renard-Clamagirand, Marobo: une société ema de Timor. Paris: Selaf, 1982.

${ }^{17}$ J. D. M. Platenkamp, "Visibility and Objectification in Tobelo Ritual", in: P. Crawford \& M. Postma (eds.), Reflecting Visual Ethnography - using the camera in anthropological fieldwork, pp. 78-102. Aarhus: Intervention Press \& Leiden: CNWS Press, 2006.
} 
can only be generated by strictly regulated ritual actions. ${ }^{18}$ All this points towards the idea, that the individual's subjective awareness of the self, of his consciousness, emotions, and moral judgements must be firmly subordinated to such a ritually constructed social 'image'.

To fulfil this task the transfer of objects is indispensible. An example from the Lao of Laos may clarify this. A newborn child consists of a body animated by the life-giving component called khuan. All khuan derives from autochthonous spiritual origins called "Old Father Past Mother" (pò kao mae: lang). The first movements of the foetus experienced by the mother-to-be signal that this khuan has begun to animate the body. During the first month of existence a newborn child has no social identity. On the contrary, still being exclusively connected to the autochthonous spiritual origin of its 'life', the child has neither a socially acknowledged gender nor a personal name, but is designated as a "spirit child" (luk phi:) instead. In the sense discussed earlier the child is 'incomplete'. To provide this "spirit child" with its social image as a Lao person, one month after birth a ritual is performed, in which matrilateral relatives transfer gift objects to it. Each of these objects communicates that social image in a specific value dimension. Embodied in the coins, jewellery, pencils or notebooks given to the infant are those social qualities (such as prosperity, marriage bliss, progeny and intelligence) that identify each giver who bestows these qualities onto the child - an idea expressed in utterances such as "I have only one earring to give to you - may you become like me". Such qualities in their totality constitute the social image that Lao society values highest. ${ }^{19}$

The Lao thus confirm Marcel Mauss' seminal observations that gift objects embody component parts of the givers, that in their transfer these parts are passed on to others, and that in the process the distinction between object and subject becomes blurred..$^{20}$ In other Southeast Asian societies similar ideas are manifest in the weapons, jewellery, porcelain or ivory objects, or coinage that are transferred in various ritual contexts. Time and again we find that only by transferring such objects the 'images' of the persons involved can be assigned a social, that is, a trans-subjective value. Such transfers express the idea that in order to socialise an individual person's 'image', that image must literally be objectified. Let me take a closer look at this phenomenon.

The 'life' that animates the bodies of humans is subject to the cycle of life and death. It is incorporated in the person during pregnancy or birth, whereas his death and the decomposition of his corpse lead to the return of this 'life' to its cosmological origins in the land. The objects transferred, however, are made from materials that resist decay. This stands to reason, for whereas at death human 'life' is alienated from the social community, the deceased's 'image' should be preserved, so as to grant the families their ancestral continuity and the society as a whole its permanence. Thus one observes that even in those cases in which the skeleton remains of the deceased are preserved to that end, in their bare form these remains are insufficient to communicate the social value that adheres to the deceased's image. That value can only be proclaimed if that 'image' is invested in enduring valuable objects and is re-integrated as such into the community of the living. Elaborate mortuary rituals, therefore, may entail the 'objectification' of human 'image' by its embodiment in

${ }^{18}$ Cf. S. J. Tambiah, "A performative approach to ritual”, Proceedings of the British Academy 65 (1979): 113-69; J. D. M. Platenkamp, op.cit.

${ }^{19}$ J. D. M. Platenkamp, "Becoming a Lao person. Rituals of birth and socialisation in Luang Prabang, Laos", in: P. Berger, R. Hardenberg, E. Kattner and M. Prager (eds.), The Anthropology of Values, Essays in Honour of Georg Pfeffer, pp. 180-200. Delhi: Pearson Education, 2010.

${ }^{20}$ Marcel Mauss, "Essai sur le don. Forme et raison de l'échange dans les sociétés archaïques", L'Année sociologique 1923/1924. 
objects such as jewellery, rock pillars, buffalo tusks, or coinage that are preserved in houses, village shrines or community graveyards.

\section{The differential origins of society}

In contrast to the autochthonous origin of 'life', the artefacts in which human 'image' can be objectified tend to be assigned an external, non-autochthonous provenance value. They may have "fallen from the skies" or have been brought from other islands or distant countries - domains that are foreign not only in the spatial but also in the cosmological sense. Along with the introduction of such imaged objects in the past, certain institutions that such objects signify make their appearance as well. With the emergence of these 'foreign' objects, laws, political offices, titles and standards of exchange - in short, a socio-political order - are introduced as well.

Numerous myths from continental and insular Southeast Asia speak of a foreign ruler making his appearance in the land in order to found such a socio-political order. To perform this task of roi civilisateur ${ }^{21}$ the immigrant ruler must relate to the autochthonous sources of 'life' - represented by the leaders of the indigenous communities and the local spirits wielding authority over these sources. It results in the establishment of diarachic orders, in which the authority is shared between the descendants of immigrants and those of indigenous ancestors. ${ }^{22}$ To the immigrants' descendants is assigned the task of communicating and exchanging with the outside world; they represent the foreign origins of valuable objects and the prestige and military prowess, which these signify. The descendants of indigenous ancestors, on the other hand, act as representatives of the autochthonous spirits in the land.

The connection between such contrasting origins, and the categories of people and objects 'descending' from them, first established in mythical time, must be reproduced time and again by means of ritual actions. In rituals of marriage and birth, healing or death objects and persons of indigenous origin (such as vegetable foodstuffs, locally produced artefacts, and marriageable women) must be exchanged against objects and persons to whom a foreign origin is ascribed (such as weapons, money and other durable valuables, and marriageable men). This does not mean that every groom himself should be, or descend from, an immigrant, but that he, his ancestors and the gifts he transfers are valued for originating abroad.

It is such conjunctions between foreign and indigenous categories of objects and persons $\mathrm{s}^{23}$ conjunctions effectuated in the ritual exchanges - that generate completeness both at the level of the person and at the level of society as a whole. For just as the complete person must be composed of a body the life of which ultimately originates in the local soil, and an image, objectified in enduring valuables of foreign origin, likewise a complete society can only come into being and be ritually reproduced if the access to the fertility of the land and the fecundity of its inhabitants is authorised by ancestors of foreign provenance.

${ }^{21}$ J. D. M. Platenkamp, "Colonial encounters in the North Moluccas: Indigenous perspectives", forthcoming.

${ }^{22}$ P. E. de Josselin de Jong, 'Ruler and realm: Political myths in western Indonesia', Mededelingen der Koninklijke Nederlandse Akademie van Wetenschappen, Afd. Letterkunde, Nieuwe Reeks, vol. 43, pp. 1-19, 1980; R. Jordaan \& P. E. de Josselin de Jong, ,Sickness as a metaphor in Indonesian political myths', Bijdragen tot de Taal-, Land- en Volkenkunde 141: 253-74, 1983.

${ }^{23}$ Such imperatives to mutually transfer persons and things of contrasting origins reflect a logic of nonequivalence exchange that contradicts both Mauss' and Lévi-Strauss' assumptions that 'reciprocity' be grounded in the equivalence logic of 'like-for-like'. 
This, then, is the core ideological message: If either the person or the society would be of autochthonous origin exclusively it would deprive either of them of their very sociality. And yet, it is this idea that appears to inform the valuation of 'strangers' in German society.

\section{4. 'Strangers' in Germany}

The current presence of most 'strangers' in Germany results from three distinct processes of immigration during the last 150 years. ${ }^{24}$ In each of these processes particular types of ideological equivalences are manifest.

The first process is that of inviting members of other societies - from Polish steelworkers and miners in the 19th century to Mediterranean and Turkish 'guest labourers' (Gastarbeiter) in the wake of the Wirtschaftswunder in the 1950s and 1960s - to contribute to the economic production of the Federal Republic of Germany. ${ }^{25}$ Their contribution should fill the gaps in the national production process, but in doing so the 'guest labourers' should not express their particular identity as 'strangers'. On the contrary, the latter identity (expressed for instance in language or religious practice) would rather be considered as an impediment to their labour productivity. Their worth for German society at large could only be measured quantitatively in reference to their contribution to the national economy. Hence it was valued in a manner fundamentally different from the contribution of the category of the 'stranger' in complementing qualitatively the socio-cosmological order in the Southeast Asian societies. As 'guest labourers' they should not be different from German labourers in any other respect than in that of their economic contribution. In other words, the 'strangers' were valued for being economically equivalent to the German labourers.

In the German Democratic Republic (GDR) the assessment of this category of 'strangers' was assigned an additional, political dimension. From the 1960s onwards, so-called 'contractual labourers' (Vertragsarbeiter) were recruited in Poland (1965), Hungary (1967), Mozambique (1979) and North Vietnam (1980) - states that shared with the GDR the same socialist ideology. Hence, whereas in the Federal Republic the 'guest labourers' were individually rewarded with wages, the contribution of 'contractual labourers' to the economic productivity of the GDR was additionally informed by an ideology of exchange between states. For once the 'contractual labourers' had returned home they would be able to apply the skills acquired to the benefit of the economic development of their home countries. In this case the exchange was defined in economic terms as well, be it that the exchange partners were declared equivalent both in economic and political terms. In the case of the GDR, 'strangers' were assigned a politico-economic equivalence.

These evaluations in economic terms subscribe to the standard axioms of monetary market economics, stipulating that monetised exchange transactions should not express any 'economically irrelevant' characteristics of the exchange partners. In both cases, the 'strangeness' of 'guest-' or 'contractual labourers' was exteriorised by transforming that into the equivalence between 'own people' and 'strangers' conceptualised in economic terms. As Louis Dumont has argued, modern political economy and homo aequalis walk hand in hand. ${ }^{26}$

${ }^{24}$ Cf. J. D. M. Platenkamp, “Über die gesellschaftliche Relevanz der Ethnologie”, in: U. Bertels u.a. (Hrsg.), Aus der Ferne in die Nähe. Neue Wege der Ethnologie in die Öffentlichkeit, pp. 21-32. Münster, 2004.

${ }^{25}$ At present there live some 2,6 million people of Turkish descent in Germany, a classification masking a considerable socio-cultural and religious heterogeneity; L. Prager, Die ,Gemeinschaft des Hauses': Religion, Heiratsstrategien und transnationale Identität türkischer Alawi/Nusairi-Migranten in Deutschland. Berlin, Münster: LIT Verlag, 2010.

${ }^{26}$ L. Dumont, Homo Aequalis. Genèse et epanouissement de l'idéologie économique. Paris 1977. 
A second wave of immigration in Germany is based on an altogether different set of values. It concerns people of "German descent" (deutscher Abstammung), who had emigrated a long time ago but are considered to still share an identity with those who stayed behind. This identity (legally conceptualised in terms of ius sanguinis, literally, "rights by blood") entitles them to 'return' to Germany as "emigrants" respectively "delayed emigrants" (Aussiedler or Spätaussiedler). ${ }^{27}$ The valuation of this category of 'strangers' in German society is clearly different from that of the 'guest labourers' in West Germany and 'contractual labourers' in East Germany. It stipulates that people who share the same cultural identity - conceptualised as a common descent from 'German origins' - are entitled to live in the same national territory and to an immediate acquisition of state citizenship. The fact that in the former Soviet Union and other eastern European countries they were stigmatised for being culturally different - more precisely, for being 'Germans' in the wake of the Second World War - morally obliged the German state to invite them to 'return home', so to speak.

Aussiedler are not expected to fill the gaps in the national economic production process but to overcome a moral dilemma, created by the dissociation between a shared cultural identity, on the one side, and membership of different nation-states, on the other. Relevant to our discussion is the fact that the Aussiedler in Germany do not represent a category of people, who are valued for complementing German society as 'strangers'. On the contrary, in spite of de facto being cultural 'strangers' in German society, they are valued for not being so. In other words, their 'strangeness' is being exteriorised by transforming that into a cultural equivalence.

The third process that has resulted in the presence of 'strangers' in Germany reflects yet another type of values. It is based on the principle, laid down in the Constitution of the Federal Republic of 1949, stipulating that people subject to state prosecution in their home country are entitled to be granted political asylum in Germany. ${ }^{28}$ In 2012, about 110,000 new asylum claims were submitted in Germany - the largest number among the world's industrialised state ${ }^{29}$ - and Germany granted more claims than any other EU member state (i.e. 17.140, against 12.400 in Sweden, 8.655 in France and 7.735 in the United Kingdom). ${ }^{30}$ One should expect this policy to be a source of collective pride to the German society at large but it seems to be valued rather as the partial redemption of a collective guilt incurred by the atrocities of the so-called 'Third Reich'.

The value to which this praxis testifies is firmly grounded in the idea of the inviolability of individual human rights. As a universally applicable principle it was codified into international law when the United Nations member states adopted the Universal Declaration of Human Rights in 1948, and it was inscribed in the Constitution of the Federal Republic of Germany of 1949 and in the Preamble of the Treaty on European Union of 2008. It is this proclaimed universality that is

\footnotetext{
${ }^{27}$ As Aussiedler are defined the almost 3 million "Germans and their relatives" (Deutsche und ihre Angehörigen) who entered Germany between 1950 and 1992; about half of them came from Poland. The circa 1,3 million Spätaussiedler, who came above all from the former Soviet Union, entered Germany between 1993 and 2000.

${ }^{28}$ Thus Article 16a of the Constitution stipulates that "victims of political prosecution are entitled to the right of asylum" ([...] politisch Verfolgte genießen Asylrecht [...]). The Article declares this right applicable to the citizens of those states in which the "protection of human rights and fundamental freedoms" ("[...] Schutz der Menschenrechte und Grundfreiheiten [...]" (Abs. 2) is not guaranteed and in which citizens are exposed to "[...] political persecution [or] inhuman or humiliating punishment or treatment [...]" (... politische Verfolgung [oder] unmenschliche oder erniedrigende Bestrafung oder Behandlung [...]"(Abs. 3).

${ }^{29} \mathrm{http} / / / \mathrm{www} . u n h c r . o r g / 532$ afe986.html, 19.3.2014.

${ }^{30}$ Eurostat 22.3.2013; http://www.proasyl.de/de/themen/zahlen-und-fakten/asyl-in-europa/).
} 
legally defined as being applicable to German and foreign people alike. The latter must be shielded by the same fundamental rights that also protect German citizens. It is not as representative of Bosnian, Algerian, or Somalian culture that one is granted asylum, but as an individual person whose universal human rights define one as subject to the same fundamental human rights as a German person. In such contexts, their 'strangeness' is subordinated to a legally defined equivalence.

\section{The German self}

At the level of the German nation-state, the 'strange' identity of immigrants tends to be negated by declaring them equivalent in economic, cultural or legal terms. In other, non-economic and nonpolitical contexts of social life, however, aesthetic, religious or intellectual expressions of 'strange' cultural traditions are incorporated without being subjected to such negating tendencies. On the contrary, such expressions not only preserve their 'strange' identity, they are also positively valued as enriching contributions to the development of the individual person.

Elaborating on the 19th century bourgeois ideal of Bildung the German person may pursue a 'completion' (Vervollkommnung) ${ }^{31}$ of the self by internalising the very expressions of 'strange'. provenance that are declared irrelevant to the socio-cultural identity of the State and its institutions. In 1890, Kaiser Wilhelm II referred to the ensuing contradiction between the person's internalisation of 'strange' cultural representations and their rejection at the level of the state, arguing that the 'classics' taught at the Gymnasium should serve to "educate young national Germans, not young Greeks or Romans". ${ }^{32}$ Concepts such as Leitkultur resonating in popular-political discourse suggest that little has changed since - be it that the 'classical' other nowadays is dressed in non-European garb. Hence one may enjoy Nigerian literature, Thai cuisine, Peruvian music, or Ayurveda healing and yet reject the idea, that immigrants are to be represented in parliament by their own political parties. And whereas Zen meditation may be celebrated as a source of metaphysical wisdom, Sufi mysticism becomes suspect when associated with Islamic precepts of a just socio-political order.

I assume such ideological configurations to characterise mutatis mutandis the value systems of other European nation-states as well. In exteriorising at the level of the nation-state what is interiorised at the level of the self they all seem to apply the Enlightenment precept that state and church be separated and religion be relegated to the domain of individual morality. It therefore should come as no surprise that this banishment of the religious and moral tenets of 'strange' cultural traditions from the political domain is contested by some of their representatives. These may challenge the "European secularists' [...] identity protection", arguing, that "[the] mass immigration of Muslims is bringing faith back into the public realm and creating a post-Enlightenment modernity for Western Europe. This return of religion threatens secular humanism, the orthodoxy that has prevailed since the French Revolution". ${ }^{33}$

\section{Conclusion}

In the context of political, social, religious and media discourses on the nation-state and the European Union, one assumes a concordance between a homogeneous 'national' political identity and an equally homogeneous socio-cultural identity. Such assumptions entail an exteriorising definition of 'the stranger' as 'the foreigner', precluding the latter from being perceived and valued

\footnotetext{
${ }^{31}$ J. Kaube, Max Weber. Ein Leben zwischen den Epochen. Berlin: Rowohlt Verlag, 2014, p. 23.

${ }^{32}$ Cited in Kaube, op.cit., p. 30; my translation.

${ }^{33}$ Irshad Manji, quoted in: Democracy Digest, Vol. 1(2), November 2004.
} 
as a constitutive part of the 'own' society as a whole. In other - non-political - contexts of social life, artistic, religious or intellectual expressions of 'strange' cultural traditions are internalised, to be valued as enriching experiences, 'completing' the personal lives of the society's members, even if these contributions are irrelevant to the socio-cultural identity of the state and its institutions.

In view of the mere presence of millions of citizens of foreign origin in west European states interacting daily with other citizens in various social contexts, the exteriorising definitions of the 'stranger' create fundamental problems. They deprive citizens of different origins of the means to conceive of their own cultural identity as a valuable contribution in itself to the society of which they have become part. The real and potential results are political indifference and social alienation. It therefore is an urgent question whether such exteriorising discourses are an inevitable corollary of any construction of socio-political identity and a necessary condition for the effective functioning of multicultural nation-states. The examples from Southeast Asia show that alternative modes of identity construction are in evidence in other, non-European societies. It may be socially and politically advantageous to take this fact properly into account.

Jos D. M. Platenkamp is Professor of Social Anthropology at the University of Muenster, Germany. He has conducted field researches in the North Moluccas (1979-1982), the Central Moluccas (1989) and Laos (1996-2006) on the systems of social organisation, cosmology and exchange, and their political and religious transformations. He is currently engaged in the French-German research project on the Local Traditions and World Religions: The Appropriation of 'Religion' in Southeast Asia and Beyond, studying the introduction and transformative impact of Christianity in the North Moluccas (1500-1900). His recent publications include: "On the confrontation between perennial models in 19th Century Halmahera (Indonesia)" (in: C. Barraud, A. Itéanu \& I. Moya (eds.), [Memorial Volume Louis Dumont], Paris, forthcoming); "Colonial encounters in the North Moluccas: indigenous perspectives", forthcoming, and "Sovereignty in the North Moluccas: Historical transformations", History and Anthropology, Volume 24(2), pp. 206-32, 2013. 